\title{
IMPROVING THE ABILITY OF BACK KICKS THROUGH THE CIRCUIT TRAINING METHOD FOR TARUNG DERAJAT ATHLETES KURATA SECOND DEGREE IN SIGINJAI MUSEUM TRAINING UNIT
}

\section{Sukendro*1}

${ }^{1}$ Sport And Health Education, FKIP, Universitas Jambi, Jambi, Indonesia

\begin{tabular}{l} 
Article Info \\
\hline Article History : \\
Received : December 2021 \\
Revised : December 2021 \\
Accepted : December 2021 \\
Available online : December \\
2021
\end{tabular}

Keywords:

Circuit Training, Exercise Method, Back Kick Ability.

\begin{abstract}
This study aims to determine the improvement of back kick ability through the Circuit Training method in fighting athletes of Kurata second degree Tarung Derajat in Siginjai Museum training unit. The method used in this study is the Sports Action Research method which was conducted on 14 athletes, with the sampling technique based on CAR (classroom action research) in sports.The implementation of this research was carried out for 2 months with a frequency of training 3 times a week or 36 meetings. In the meeting, circuit training was given at each meeting to improve the ability of back kicks. Data analysis was carried out by means of data exposure and data reduction.Based on the table description of the results of the initial test of the first cycle of back kick ability, it can be seen that the kick ability of the athletes of Kurata second degree Tarung Derajat in the Siginjai museum training unit is still relatively low. It can be seen from the 14 athletes who were the subjects in this study, it turned out that only 9 athletes $(64 \%)$ had complete results, while the remaining 5 athletes $(36 \%)$ did not have complete training results than the expected $70 \%$ in cycle II action.In the results of the second cycle test, it can be seen an increase in back kick ability. It can be seen from the 14 athletes who were the research subjects that there were 13 athletes (98.2\%) who achieved graduation. Meanwhile, only 1 athlete (7.1\%). Judging from these results, it can be concluded that the Circuit Training method can improve the ability of back kicks in athletes of Kurata second degree Tarung Derajat in siginjai museum training unit.
\end{abstract}

Corresponding address : Jl. Kenanga III no. 22 Rt.05 Simpang IV Sipin Telanaipura Regency Jambi Province.

*Corresponding email : sukendrodasar@yahoo.co.id
ISSN 2685-6514 (Online) ISSN 2477-331X (Print) 


\section{INTRODUCTION}

Sport is a form of physical activity contained in competitive games from intensive activities in order to obtain recreation, victory and peak performance. Sport has many functions, namely for training, educational tools, livelihoods, cultural media, spectacle materials, health development facilities, diplomacy and no less important as the pride of the State or nation. The process in sport is in the form of all activities or businesses that can encourage developing and fostering one's physical and spiritual potential.

According to Sajoto (1995), there are four basic human goals for carrying out sports activities. First, those who carry out sports activities only for recreation. Second, those who carry out sports activities for educational activities. Third, those who carry out sports activities with the aim of achieving a level of physical health. Fourth, those who do sports activities for achievement.

One of the goals of sport is to achieve achievement. To obtain these achievements is not easy, requires time and process, as well as intensive coaching. Achievement in sports is the result obtained or achieved by someone through sports activities. These results can be seen from the physical and motoric abilities or techniques and mental abilities of an athlete in various exercising types of achievement sports are competed, self-defense is included in the sports that are competed. Self-defense is one of the sports that is developing in Indonesia. As for martial arts sports originating from foreign countries, such as Taekwondo, Karate, Kempo, Judo and many more that have not we know. In Indonesia, there are only a few original martial arts from Indonesia, such as Pencak Silat and Boxer, or better known as Tarung Derajat.
Each sport has its own technique and differs from one sport to another. Therefore, the technical training given to athletes must be adjusted and refers to the technical characteristics of the sports required in the competition.

As in the case of fighting sports, in achieving an achievement, it must first begin with the development of the athlete's physical condition, in addition to the technical, tactical, strategy and mental components. Technique is a component of sports achievement which is one component of sports achievement which is a feature or characteristic of a sport, therefore, the technical component must be prepared as well as possible. Good mastery of technique will be able to save and optimize the use of physical conditions. That means, a good mastery of technique will be able to help save energy usage.

This means that the better the technical mastery of a sport, the more efficient it is in the use of energy expended. In addition, among technique and physical conditions have a relationship with each other. The development and mastery of technical skills is largely determined by the level of physical condition possessed, in other words that in good physical condition it is impossible for techniques to be improved and strengthened.

In Tarung Derajat there are five elements of motion in each fighting technique that is driven, namely strength, speed, accuracy, courage, and tenacity. These five elements of motion must be possessed by members of the Tarung Derajat (KODRAT) family to be able to hit and kick well, especially when fighting in performing punching and kicking techniques in combat.

Tarung derajat have basic techniques, namely fast punches, inner circle punches, upper ring punches and outer ring punches. While the kick 
technique uses the inner circle kick, side kick, back kick, back circle and hook kick. The back kick is a very effective kick used during the fight, why is it said to be effective because this kick is a kick that has a very good chance if this kick is done correctly, because it is the most appropriate to use to subdue or paralyze the opponent when competing correctly and can collect as many points as possible to win

Researchers observed Tarung Derajat in Siginjai Museum training unit, Jambi City. Often the members of fighting degrees in performing deep back kicks are difficult to maintain balance and regulate the accuracy and speed of kicks on the target. In addition, observations in the field at the Siginjai Museum training unit, Jambi City, were still found by many fighting members whose kicks were not on target in kicking the ped. Kick used in practice and weak kick speed in moving the foot to kick the kick precisely at the target suggestion.

This does not only happen in the training unit, as evidenced by the fact that after kicking the fighter does not retract the knee of their leg, and there is also a kick towards the opponent's groin, this causes the fighter to be subject to a violation and even disqualification during the match and experience defeat.

From this situation, the author tries to do research on kicking techniques, especially back kicks. Which researchers will try to improve the kick technique, even though the athlete already knows the basic back kick technique which in the execution of the movement is still not good. So from this study the author tries to provide circuit training exercises. This method consists of several posts, and each post is given a different form of exercise according to the purpose of the exercise, so that the training given using this method can improve the back kick of the Kurata second degree athletes in the Siginjai Museum training unit.

Based on the description above, the author is interested in conducting research with the title: "Improving the ability of back kicks through the circuit training method for fighting athletes Kurata second degree Tarung Derajat in Siginjai Museum training unit".

The objectives of this study is to determine the improvement of back kick ability through circuit training in Kurata second degree athletes in the Siginjai Museum training unit.

The results of this study are expected to provide benefits for the author himself in particular the related parties in general as follows:

1. Theoretical benefits

To solve the problems faced and are expected to provide benefits for the progress of a coaching in improving sports achievement, especially the branch of combat sports.

2. Practical benefits

A. Benefits for trainers: getting training innovations and training alternatives as well as improving and developing professional trainers' abilities in training.

B. Benefits for athletes: increase self-confidence; achieve maximum training results; provide a new atmosphere in practice.

\section{METHODS}

Research instruments or often referred to as measuring instruments and are taken with test techniques. In this case the research instrument is also defined as a tool selected and used by researchers in their research to collect data (arikunto: 2006). In principle, research is to take measurements, so there must be a good measuring instrument. The measuring instrument in research is called research instrument. The research instrument is a 
tool used to measure natural and social phenomena of interest. Instruments are tools used in collecting data arikunto (2006). The instrument used in this study is a process assessment with a back kick test portfolio. In this test, the athlete is asked to perform a back kick technique (initial stance, foot and body position, and final position).

\section{Participants}

The subjects of this study were combat athletes of the second degree kurata in the training unit of the siginjai museum. The number of combat athletes in the training unit of the siginjai museum was 14 people.

\section{Sampling procedures}

The sample of this research is total sampling. It means all tarung derajat athletes in the siginjai museum training unit as many as 14 people.

Sources of data in this sports action research (sar) are as follows:

1. Athletes, to obtain data on the back kick technique using the circuit training method for tarung derajat athletes with the training unit at the siginjai museum.

2. Coach, to see the success rate of back kicks through the circuit training method of fighting athletes with degrees in the siginjai museum training unit.

\section{Design or data analysis}

In accordance with this study, the first step in determining the method used in the study, namely the sports action research method, then this research will be carried out in several stages in the form of cycles but before entering the cycle, first carry out the following activities.

Athletes who were used as research subjects were directed to do a free test, to do back kicks and the test results of these athletes were used as initial test results in this study, while what was used in this study was the kick technique. After getting the results of the free test, then observations and evaluations were held to see the existing problems that had been causing the athlete's low skills in performing the back kick technique. After that enter the cycle in question:

Cycle i

a. Action planning stage $i$

At this stage the activities carried out are planning actions, researchers collaborate with coaches to create training programs that are tailored to the athlete's abilities using the following methods:

1) Researchers analyzed the design of the exercise program using the circuit training method that would be given to athletes.

2) Loading an exercise program plan with reference to the actions that refer to the actions applied to the sar.

3) Arrange the instruments used in the sar cycle, assessment of back kick techniques.

4) Prepare the necessary media to help the training process

5) Develop an exercise evaluation tool. Next, determine an alternative plan of action.

b. Implementation of actions $i$

After the planning has been carefully prepared, action is taken against the athlete. At this stage the researchers carried out an exercise program in the field with the following steps:

1) Explaining the activities that will be carried out, the coach explains to the athletes how to implement the training program using the circuit training method. The coach explains to the athlete about the implementation of circuit training. This exercise consists of six posts, each post has a different form of exercise with the same goal of improving kick technique. The forms of the exercise are: post one athlete doing 
splits in pairs, post two athletes doing a 20 meter split, post three athletes doing squats, post four athletes swinging their legs back at head height to form a $90^{\circ}$ angle, post five athletes doing back kicks with encouragement which is a slow position where the legs are raised to waist level parallel to the legs then push backwards at an angle of $90^{\circ}$, post six athletes perform back kicks with power boost quickly and precisely on the target and balanced without rocking. Implement training programs starting from warming up (warming up), core workout, cooling down.

2) Assessment is carried out during the exercise.

3) Draw conclusions

c. Observation of action i

At this stage, observations are made on the implementation of the action using the observation sheet that has been compiled. The researcher is on duty as an observer, fill out the observation sheet to see if the training conditions have been carried out according to the exercise program when the action is carried out.

d. Reflection i

The results obtained from the action and observation stages are collected and analyzed at this stage, so that it can be concluded from the actions taken from the results of the first exercise test results. When the results of reflection do not increase by $70 \%$, then proceed with cycle ii.

\section{RESULT}

The description of the research data is in accordance with the results of the initial actions taken on tarung derajat athletes of kurata second degree at the siginjai museum. The problem that occurs is, not all of the back kick abilities are categorized as good.
The description of the results of the initial test (pre-test) obtained by athletes can be seen in the following table below:

Description of result data before the back kick ability training program was implemented.

Table 1.

\begin{tabular}{|c|c|c|c|c|}
\hline No & $\begin{array}{l}\text { Test } \\
\text { results }\end{array}$ & $\begin{array}{l}\text { Number } \\
\text { of athletes }\end{array}$ & $\begin{array}{l}\text { Percen } \\
\text { tages }\end{array}$ & Description \\
\hline 1 & $\begin{array}{l}\text { Score } \\
70\end{array}$ & & $50 \%$ & Completed \\
\hline 2 & $\begin{array}{l}\text { Score } \leq \\
70\end{array}$ & & $50 \%$ & Uncompleted \\
\hline
\end{tabular}

based on the description table of the test results before the back kick ability training program was implemented, it can be seen that the kick ability of the tarung derajat athletes kurata second degree museum siginjai is still relatively low. Of the 14 athletes who were the subjects in this study, it turned out that only 7 athletes $(50 \%)$ had complete training results, while the remaining 7 athletes $(50 \%)$ did not have complete training results. The average value of the athlete's back kick ability is $50 \%$. For more details can be seen in the graph below.

\section{Results of Back Kick Pre Test}

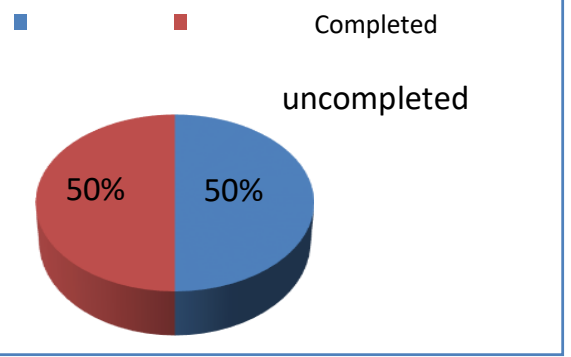

Figures 1.

a. Action plan i

The action plan $\mathrm{i}$ was prepared to overcome the problems that occurred in athletes in mastering the ability of 
back kicks. The solution to the problem was to carry out a training program in the field that had been prepared previously. At this stage, the researcher carried out an exercise program in the field with the following activity steps:

1) The researcher analyzes the design of the exercise program using the circuit training method that will be given to athletes.

2) Make an exercise program plan with reference to the actions implemented in the sar.

3) Arrange the instruments used in the sar cycle, assessment of back kick technique

4) Prepare the necessary media to assist the training process.

5) Develop an exercise
evaluation tool.

After that, the researcher determine alternative action plan if there is no significant increase.

b. Implementation of action $i$

After the planning is prepared, action is taken against the athletes. At this stage, the researcher carried out an exercise program in the field with the following activity steps:

1) Prepare an exercise program that has been made as an effort to solve problems $i$.

2) Describe the activities to be carried out. The trainer explains to the athletes how to implement the training program using the circuit training method. The coach explains to the athlete about the implementation of circuit training.

3) Implement training programs starting from:
- Warming up (warming up),

- Workout core,

- Cooling down.

4) Assessment is carried out during the exercise.

5) Draw conclusions

c. observation and evaluation $\mathrm{i}$

At this stage, observations and evaluations are carried out on the implementation of the actions taken. Researchers helped as observers assisted by trainers and other assistant trainers to see the shortcomings that occurred from the beginning of the implementation of the exercise action, through the circuit training method that had been arranged in 6 posts, with different exercise movements in each post in order to improve the ability of back kicks in fighting athletes of kurata second degree at the siginjai museum.

d. Data analysis i

After the first observation and evaluation process was carried out, the data analysis process was carried out from the results of the first exercise obtained.

From the data on the results of the first cycle of training after the implementation of the training program, the results obtained show that the athlete's ability to test the results of classical training has not increased, although there are still athletes who have not achieved completeness. Of the 14 athletes there are 9 athletes (64\%) who have achieved complete training, while 5 athletes $(36 \%)$ have not achieved completeness from the results of the exercise. With a score that has not reached the $\mathrm{kkm}$ (minimum completeness criteria). For more details, it can be seen in this graph: 


\section{a. Data reflection}

From the data analysis that has been carried out, it can be concluded that through the use of the circuit training method using the postal system, which is in the form of different exercises in each post totaling 6 athlete posts, it can improve the ability of back kicks. The results obtained show that the athlete's ability to test the results of classical training has not increased, although there are still athletes who have not yet reached completeness. Of the 14 athletes there are 9 athletes (64\%) who have achieved complete training, while 5 athletes (36\%) have not achieved completeness from the results of the exercise. If the score has not reached the $\mathrm{kkm}$ (minimum completeness criteria) then it will be continued in cycle ii.

\section{DISCUSSION}

Based on the description of the research data, this study found that after the action was given in the first cycle, the minimum completeness criteria had not reached $70 \%$. It can be seen from the 14 athletes who were the subjects of the study that there were 13 athletes $(98.2 \%)$ who achieved graduation. Meanwhile, only 1 athlete $(7.1 \%)$. From the results in the second cycle, the achievement of $98.2 \%$ has reached the minimum completeness criteria of $70 \%$. Judging from these results, it can be concluded that the circuit training method can improve the ability of back kicks of tarung derajat athletes of kurata second degree the siginjai museum training unit. The ability of back kicks in athletes of kurata second degree training unit at the siginjai museum.

From the initial test until the cycle $\mathrm{i}$ was carried out and research was carried out through observation sheets there was an increase, in this case it can be said that through the circuit training method, it can improve the back kick ability of tarung derajat athletes with kurata second degree at the siginjai museum.

Completeness is obtained for the following reasons:

1. Circuit training is focused on improving back kick skills

2. Every wrong movement is immediately given treatment, or an evaluation to provide a solution so that the athlete understands the correct movement

From the 14 athletes there are 7 athletes who have achieved the level of completeness of the results of the exercise while 7 athletes have not completed the results of the exercise with an average value $50 \%$. Then, the first cycle was given treatment in the end an assessment of the back kick was carried out, there were 9 athletes who completed their training results with an average value of $64 \%$. In the second cycle of exercise can achieve completeness. As for the results of the second cycle of training given, from a total of 14 athletes there were 13 athletes who had reached the level of completeness of back kick training results with an average value of $92.8 \%$. To see more clearly about the data on the results of the exercise in cycle $i$ and cycle ii and the data on the development of the results of the exercise in cycle and cycle ii.

Based on the table describing the results of post-test i above, it can be seen that the back kick ability has actually improved. Of the 14 athletes who as a subject in this study, it turned out that there were 13 athletes $(92.8 \%)$ who had complete or successful training, while 1 athlete (7.1\%) still did not have complete or successful training.

\section{CONCLUSION}

Based on the observations of researchers before the first cycle in 
fighting athletes, the degree of the problem that occurred was that the athlete's back kick ability was not all categorized as good. Of the 14 athletes only $7(50 \%)$ athletes have complete training results, while 7 (50\%) athletes do not yet have complete back kick training results. In the first cycle after being given the circuit training method training from 14 athletes 9 athletes who had complete training results (64\%) and 5 more athletes did not have complete training results $(36 \%)$ in cycle ii of 14 athletes only 13 athletes had 92 completeness, $8 \%$. While 1 person $7.1 \%$ did not complete. So every exercise from cycle $\mathrm{i}$ and cycle ii has increased. The increase occurred due to:

a. In training, athletes are serious in doing motion and understanding the material given.

b. In improving the movement of coaches and researchers directly provide solutions to the mistakes made by athletes.

from the results of the research above, it can be concluded that the circuit training method can provide a very large and significant increase in back kicks in second-degree fighting athletes.

\section{ACKNOWLEDGEMENT}

Thank you to all who have helped in this research including, kang engkos, kang syamsu, ananda neny and others who cannot be mentioned one by one, hopefully it will be a charity of worship for all of us. Amin.

\section{REFERENCES}

Arikunto. Suharsimi. 2015. Prosedur Penelitian Suatu Pendekatan Praktik.( edisi revisi ) Jakarta: Rineka cipta.

Azizah, Layla 2012. Dalam Skripsi Ain Sadalia
Dewi LB. 2009. Metodologi Penelitian IlmuIlmu Kesehatan. Multazam Bandung. Hlm. 80

Harsono. 2015. Periodesasi Program Latihan. PT. Remaja Rosdakarya Bandung. Hlm. 31.

Harsono. 2015. Kepelatihan Olahraga. PT. Remaja Rosdakarya Bandung. Hlm.50

Harsono. 2016. Latihan Kondisi Fisik ( Untuk atlet dan Kesehatan). PT. Remaja Rosdakarya Bandung. Hlm. 54

Hamzah, dkk. 2014. Variabel Penelitian dalam Pendidikan dan Pembelajaran. PT. Ina Publikatama Jakarta. Hlm.331

Paidon. L. 2008. Performance Nutrition. Menpora. Jakarta. Hlm. 261

Punaji. S. 2013. Metode Penelitian Pendidikan dan Pengembangan. PT. Fajar Interpratama Mandiri. Jakarta. Hlm. 195

Musium Olahraga (2016) Patriot yang Membahana, Jakarta. Hlm.45

Tatang, dkk. 2016. Metode Penelitian Pendidikan. Mitra Wacana Media. Jakarta. Hlm. 12

Widiastuti. 2011. Tes dan Pengukuran Olahraga. PT. Bumi Timur Jaya. Hlm. 1

Winarno. 2011. Metodologi Penelitian Dalam Pendidikan Jasmani. Media Cakrawala Utama Malang . Hlm.62

Yosua Praditya. 2017. Olahraga Membangun bangsa. Jakarta. Hlm. 149

Sukendro. 2015. Gizi dan Kesehatan Olahraga. Corbooks. Bandung. Hlm.5 